\title{
Glutamate Transport by Rcho-1 Cells Derived From Rat Placenta
}

\author{
DONALD NOVAK AND JAMES MATTHEWS \\ University of Florida College of Medicine, Gainesville, FL 32610, U.S.A.
}

\begin{abstract}
ABSTR
Marginal giant cells within the rodent placenta are important
sources of androgens, critical to maintenance of pregnancy.
Androgen synthesis requires NADPH, a by-product of glutamate
oxidation. We examined the uptake of glutamate into rat chorio-
carcinoma cells, which have been shown to maintain many of the
characteristics of marginal giant cells in culture. Na ${ }^{+}$-dependent,
D-aspartate inhibitable uptake consistent with System $\mathrm{X}_{\mathrm{AG}}-$
mediated transport was present, as were proteins capable of
System $\mathrm{X}_{\mathrm{AG}}-$ activity, EAAC1, GLAST1, and GLT1. Glutamate
uptake in rat choriocarcinoma cells was up-regulated by amino
acid deprivation-a response that was not reversed by the addi-
tion of glutamate to the media. Inhibition data suggested up-
\end{abstract}
regulation of transport activity mediated by either EAAC1 or GLAST1 at $6 \mathrm{~h}$, whereas at 24 and $48 \mathrm{~h}$, up-regulation of GLT1 plays an increasing role. Levels of EAAC1 immunoreactive protein increased with time under amino acid depleted conditions, whereas those of GLAST1 and GLT1 remained stable or declined but not significantly. (Pediatr Res 53: 1025-1029, 2003)
Abbreviations
MeAIB, (methylamino)isobutyric acid DHK, dihydrokainate
KRP, Krebs-Ringer phosphate

The rat placenta is an anatomically heterogeneous organ. Nutrient transfer from maternal to fetal circulations is generally assumed to occur in the labyrinth region. Maternal blood, however, also directly bathes cells within the junctional zone, including spongiotrophoblast basophilic cells, glycogen cells, and marginal giant cells (1). Each of these cell types is thought to have specific and unique functions. Perhaps the best described of these is the production of steroid and polypeptide hormones by marginal giant cells (2-5). Specifically, these cells produce androstenedione, important in the maintenance of pregnancy $(2,6-8)$. The synthesis of androstenedione is an NADPH-dependent process (8). Maintenance of adequate cellular NADPH, therefore, is important. NADPH is derived as a by-product of glutamate oxidation. In fact, the metabolism of glutamate, shown in the human placenta to occur primarily through the transferase and deamination pathways, with subsequent incorporation into the tricarboxylic acid cycle (9), produces a variety of important energetic intermediates, including NADPH, NADH, reduced flavin adenine dinucleotide, and guanosine triphosphate. Given the relatively low activity of pentose phosphate shunt enzymes in human and rat placenta, the NADPH produced from glutamate by cytoplasmic gluta-

\footnotetext{
Received December 18, 2001; accepted November 18, 2002.

Correspondence: Donald Novak, Box 100296, University of Florida College of Medicine, Gainesville, FL 32610-0296, U.S.A.; e-mail: novakda@peds.ufl.edu

This work was supported by grant HD-29934 from the National Institutes of Health.

DOI: 10.1203/01.PDR.0000061542.06874.2A
}

mate dehydrogenase has been hypothesized to be important in placental steroidogenesis and, to a limited degree, in lipogenesis (10-14). In fact, the production of progesterone, also an NADPH-dependent process, in mitochondria isolated from human placenta is increased in the presence of supplemental glutamate $(7,14)$. Hence, characterization of glutamate transfer into marginal giant cells within the rat placenta is of importance.

Rat choriocarcinoma (Rcho-1) cells, in the differentiated state, possess a secretory profile that is consistent with that of the trophoblast giant cell, producing both androstenedione and progesterone $(7,15,16)$. The synthesis of both hormones involves the NADPH-dependent cytochrome P450 enzyme system (7). Given that NADPH is a product of glutamate metabolism, we examined glutamate transport activity and substrate-dependent regulation in differentiated Rcho-1 cells.

\section{METHODS}

Chemicals. $\left[{ }^{3} \mathrm{H}\right]$ glutamic acid was obtained from American Radiolabeled Chemicals (St. Louis, MO, U.S.A.). All other chemicals were of reagent grade or of the highest grade commercially available. The EAAC1 antibody was made as previously described (17). GLT1 and GLAST1 antibodies were the gift of Jeffrey Rothstein (Johns Hopkins University, Baltimore, MD, U.S.A.).

Cell culture. Rcho-1 cells were the gift of and were grown as described by Soares and colleagues $(18,19)$. For inducing 
hormonal and morphologic differentiation, Rcho-1 cells were grown to confluence in 175 -mm flasks in NCTC-135 media with $20 \%$ fetal bovine serum, passed into 24 -well trays, and then switched to media containing $5 \%$ horse serum but no fetal bovine serum. Cells were plated at $80 \%$ confluence unless otherwise noted. Amino acid depletion experiments were initiated by changing media to Selectamine (GIBCO BRL) media (no added amino acids; $5 \%$ dialyzed horse serum) with addition of the designated amino acid in a concentration of $1 \mathrm{mM}$ for 6, 24, or $48 \mathrm{~h}$.

Uptake. Whole-cell uptake measurements were performed as previously described using cells seeded into 24-well dishes as described above (20). Uptake was initiated by replacing depletion (amino acid free) buffer $\left(2 \times 15\right.$ min) with $\mathrm{Na}^{+}$containing Krebs-Ringer phosphate (KRP) or $\mathrm{Na}^{+}$-free (choline KRP) buffers that contained the appropriate amount of radiolabeled $(10 \mu \mathrm{Ci} / \mathrm{mL})$ and unlabeled L-glutamate and, when indicated, inhibitors. After the appropriate time interval, which was typically $<60 \mathrm{~s}$, uptake was terminated by four rinses of $4^{\circ} \mathrm{C}$ choline-KRP $(2 \mathrm{~mL} /$ well). After air-drying, cellular protein was precipitated with $10 \%$ trichloroacetic acid, and the supernatant radioactivity was quantified by liquid scintillation counting. Subsequently, the precipitated proteins were solubilized in $0.2 \mathrm{~N}$ sodium hydroxide $/ 0.2 \% \mathrm{SDS}$ and analyzed for total cellular protein. Uptake velocities (uptake . $\mathrm{mg}^{-1}$ protein $\cdot \mathrm{min}^{-1}$ ) are reported as the mean \pm SE unless otherwise noted; derived (i.e. $\mathrm{Na}^{+}$-dependent, starvationinduced) velocities were obtained by subtracting uptakes in the absence of $\mathrm{Na}^{+} /$presence of inhibitor from that in the presence of $\mathrm{Na}^{+}$or absence of inhibitor.

Western analysis. Protein aliquots $(50 \mu \mathrm{g} / \mathrm{lane})$ were electrophoresed on $7.5 \%$ SDS-polyacrylamide by the method of Laemmli (21). Proteins were electrotransferred to a $0.45-\mu \mathrm{m}$ nitrocellulose membrane, and blots were probed with the specified amount/dilution of antibody using previously described conditions (17). For the detection of EAAC1 protein, blots were probed with $43 \mathrm{ng} \mathrm{IgG} / \mathrm{mL}$ of the EAAC1 polyclonal antibody or preimmune sera in blocking solution [1\% nonfat dry milk and $2 \%$ casein hydrolysate in $10 \mathrm{mM}$ Tris- $\mathrm{HCl}(\mathrm{pH}$ 7.5) and $300 \mathrm{mM} \mathrm{NaCl}$ ] for $1 \mathrm{~h}$ at room temperature with agitation. For the detection of GLAST1 and GLT1 proteins, blots were probed with rat GLAST1 $(320 \mathrm{ng} \mathrm{IgG} / \mathrm{mL})$ or rat GLT1 (68 $\mathrm{ng} \mathrm{IgG/mL)} \mathrm{antibodies} \mathrm{as} \mathrm{described} \mathrm{previously} \mathrm{(22).}$ Immunoreactive bands were detected with Protein A conjugated to horseradish peroxidase or horseradish peroxidaseconjugated secondary antibody $(1: 1000)$, as appropriate. Visualization was performed with an enhanced chemiluminescence kit (Amersham Biosciences, Piscataway, NJ, U.S.A.). These antibodies have been previously validated and found to be specific through the use of preincubation of primary antibody with the appropriate peptide or fusion protein against which each antibody was made, with subsequent disappearance of visible bands. The presence of multiple bands on immunoblotting of these transport proteins has been noted previously, by both ourselves and others (23). We have previously shown that the bands visualized compete with specific peptide (17). Thus, all visible bands were included in the analysis. Densitometry was performed using National Institutes of Health software.
Data analysis. Differences between groups were evaluated using $t$ test or by the test of differences of means (in the case of derived values, such as $\mathrm{Na}^{+}$-dependent uptakes). Regression lines were calculated with SigmaPlot (SPSS, Inc., Chicago, IL, U.S.A.)

\section{RESULTS}

Glutamate uptake into apical and basal membrane vesicles derived from rat placental labyrinth has previously been demonstrated to occur via System $\mathrm{X}_{\mathrm{AG}}{ }^{-}$(17). For determining whether Rcho-1 cells were capable of glutamate transport, the uptake of $1 \mu \mathrm{M}$ glutamate was evaluated in the presence and absence of $\mathrm{Na}^{+}$(Fig. 1). Glutamate uptake was, for the most part, $\mathrm{Na}^{+}$-dependent and linear through at least 5 min. A significant portion of uptake was inhibited by D-aspartate (Fig. 2); this uptake was attributed to System $\mathrm{X}_{\mathrm{AG}}{ }^{-}$.

System $\mathrm{X}_{\mathrm{AG}}{ }^{-}$activity is up-regulated by substrate deprivation in HRP. 1 cells derived from midgestation rat placenta, as well as in a renal epithelial cell line $(24,25)$. Accordingly, the influence of amino acid deprivation on glutamate uptake by Rcho-1 cells was evaluated (Fig. 3). Compared with the nondepleted (control) treatment, amino acid depletion resulted in System $\mathrm{X}_{\mathrm{AG}}{ }^{-}$-mediated glutamate uptakes that were significantly increased by at least 4 -fold at 6,24 , and $48 \mathrm{~h}$. As contrasted to previous studies performed in HRP.1 cells (derived from rat placental labyrinth), the addition of $1 \mathrm{mM}$ glutamate did not abrogate this stimulatory effect $(17,24)$. Although no tested amino acid, by itself, entirely abolished the amino acid deprivation-induced increase in activity at each time point, glutamine, leucine, and $\alpha$-(methylamino)isobutyric acid (MeAIB), a nonmetabolizable amino acid analogue substrate of System A, had intermediate effects.

Five amino acid transporters capable of glutamate transport consistent with System $\mathrm{X}_{\mathrm{AG}}{ }^{-}$activity have been cloned. We

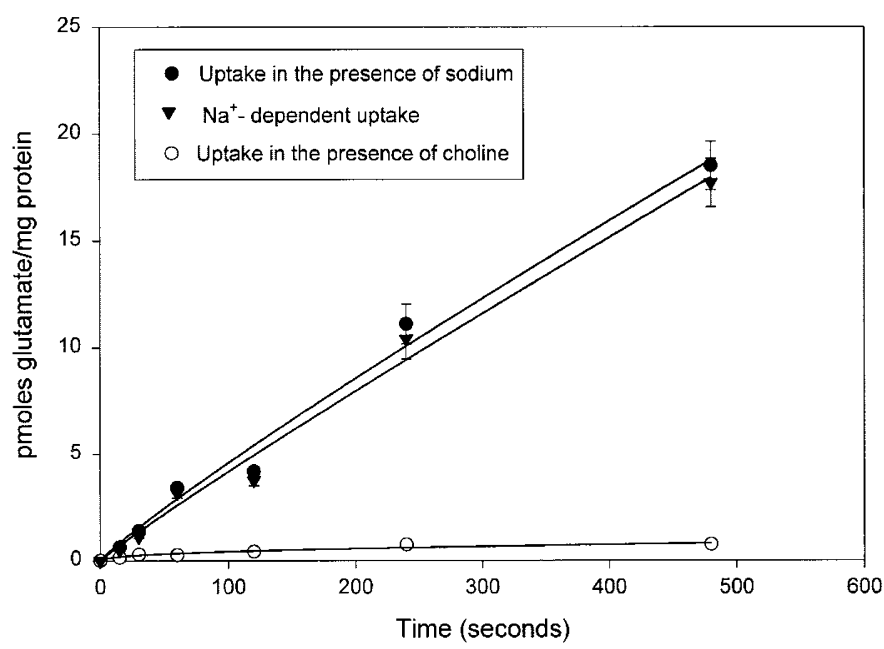

Figure 1. Time course of glutamate uptake into Rcho-1 cells. The transport of $1 \mu \mathrm{M}\left[{ }^{3} \mathrm{H}\right]$ glutamate into Rcho-1 cells at $80 \%$ confluence is depicted. Conditions are as depicted; uptake was performed in either the presence of 100 $\mathrm{mM} \mathrm{Na}{ }^{+}$or choline gradients. $\mathrm{Na}^{+}$-dependent uptake was calculated by subtracting uptake in the presence of choline from that in the presence of $\mathrm{Na}^{+}$. All data points represent mean $\pm \mathrm{SE}$ of pooled data points from replicate experiments. Lines are best-fit regressions calculated from the data points. 


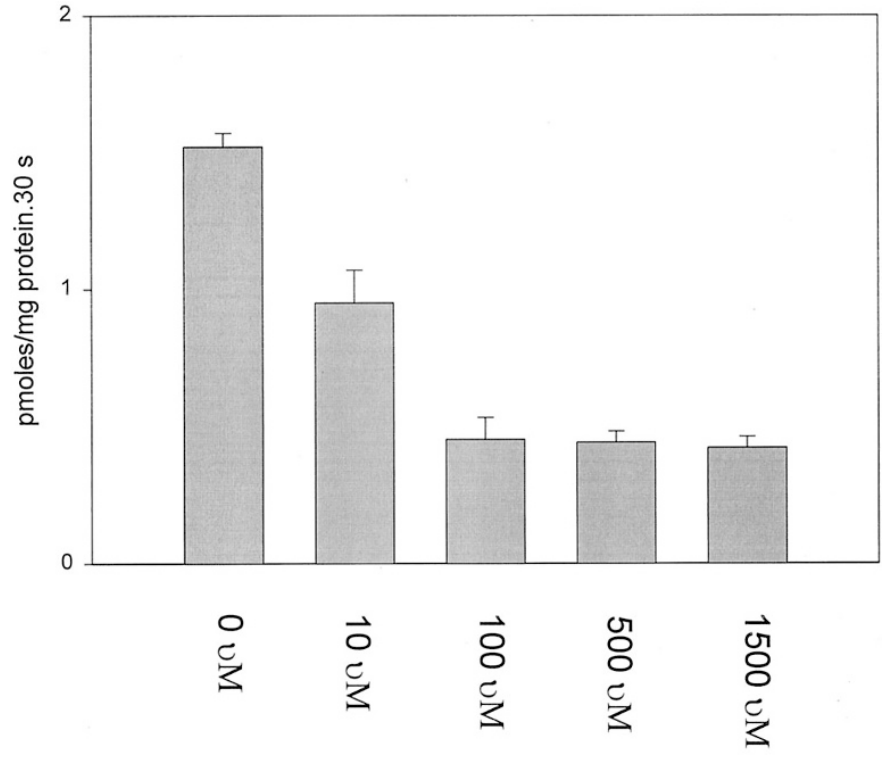

Figure 2. Inhibition of $\left[{ }^{3} \mathrm{H}\right]$ glutamate uptake into Rcho- 1 cells by varied concentrations of D-aspartate. The $\mathrm{Na}^{+}$-dependent transport of $1 \mu \mathrm{M}\left[{ }^{3} \mathrm{H}\right] \mathrm{glu}-$ tamate into Rcho- 1 cells at $80 \%$ confluence is depicted. Points shown are mean $\pm \mathrm{SE}$ of pooled 30 -s observations from replicate experiments.

have previously demonstrated the presence of three of these, EAAC1, GLT1, and GLAST1, in rat placenta, as well as in HRP.1 cells $(17,24)$. To explore the mechanism by which glutamate uptake was enhanced by amino acid depletion, we used previously characterized antibodies directed against EAAC1, GLT1, and GLAST1 to perform immunoblotting of Rcho-1 cell homogenates in the presence/absence of amino acids. As depicted in Figures 4 and 5, GLT1 immunoreactive protein was unaffected at $6 \mathrm{~h}$ by any study condition. In contrast, GLT1 content was diminished by approximately $50 \%$

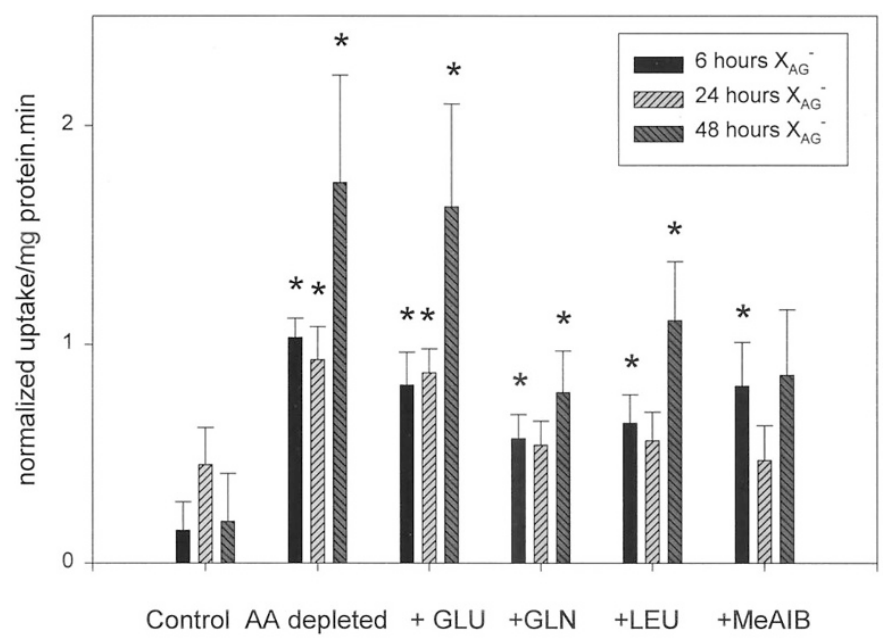

Figure 3. Influence of amino acid depletion upon System $\mathrm{X}_{\mathrm{AG}}{ }^{-}$-mediated uptake in Rcho-1 cells. Experiments were performed as detailed in "Methods." Each point represents the mean $\pm \mathrm{SE}(n=6)$ of 1 -min uptakes normalized (to compensate for interexperiment variability, $n=3$ ) to total uptake of $1 \mu \mathrm{M}$ $\left[{ }^{3} \mathrm{H}\right]$ glutamate in the presence of amino acids. Control, normal complement of amino acids in Selectamine media; AA-depleted, lack of amino acids in media; GLU, glutamate; GLN, glutamine; LEU, leucine. Significance of differences between groups was determined by using the test of differences of means $\left({ }^{*} p\right.$ $\leq 0.05)$.

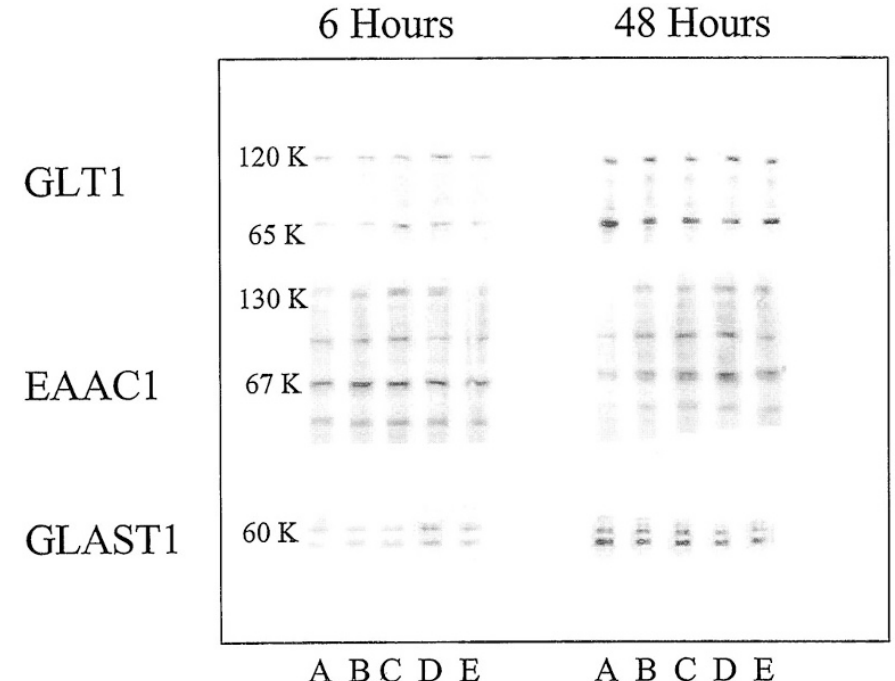

Figure 4. Immunoblot analysis of System $\mathrm{X}_{\mathrm{AG}}{ }^{-}$transport proteins in Rcho-1 homogenates. Images shown are representative of immunoblots performed on cellular proteins derived from at least three replicate experiments. Equal protein loading was ensured by fast green staining before immunoblot analysis. $\mathrm{A},+$ amino acids; $\mathrm{B}$, minus amino acids; $\mathrm{C},+1 \mathrm{mM}$ glutamate; $\mathrm{D},+1 \mathrm{mM}$ glutamine; E, + $1 \mathrm{mM} 2$ - MeAIB.

after $48 \mathrm{~h}$ in culture in the presence of $1 \mathrm{mM}$ glutamine. All other experimental conditions were similar to amino acidreplete controls. EAAC1 immunoreactive protein was increased in Rcho-1 cell homogenates at $6 \mathrm{~h}$ in amino aciddepleted cells and glutamate-supplemented cells. No increase in EAAC1 content compared with amino acid-replete control was seen when either glutamine or MeAIB was added to the media. After $48 \mathrm{~h}$, EAAC1 content in amino acid-depleted cells was increased approximately 2.5 -fold compared with amino acid-replete control. Significant increases were also noted in the presence of glutamine and glutamate; although EAAC1 content was also increased in the presence of MeAIB, this difference did not reach significance $(p \leq 0.08)$. Immunoreactive GLAST1 was unaffected at $6 \mathrm{~h}$ by amino acid depletion compared with control. This effect persisted despite the addition of either glutamate to the media, whereas the addition of glutamine produced a significant increase in protein content. At $48 \mathrm{~h}$, immunoreactive protein contents were not different from control in any group.

We have previously shown in HRP. 1 cells that the enhancement in glutamate uptake brought about by amino acid deprivation could be accounted for, to a significant degree, by an increase in dihydrokainate (DHK)-inhibitable activity (24). In the present studies, at $6 \mathrm{~h}$, transport activity induced by amino acid deprivation was inhibited by D-aspartate, an inhibitor of GLT1, GLAST1, and EAAC1, to a significantly greater degree than by DHK, an inhibitor of GLT1 but not EAAC1 or GLAST1 (Fig. 6) (26). This observation indicates that EAAC1 and/or GLAST1 activity was primarily responsible for the observed System $\mathrm{X}_{\mathrm{AG}}{ }^{-}$-mediated glutamate uptake. In contrast, after 24 and $48 \mathrm{~h}$ in culture, GLT-1 seemed to be responsible for the increase in System $\mathrm{X}_{\mathrm{AG}}{ }^{-}$-mediated glutamate uptake induced by amino acid deprivation as the amount of D-aspartate-inhibitable and DHK-inhibitable uptake did not 

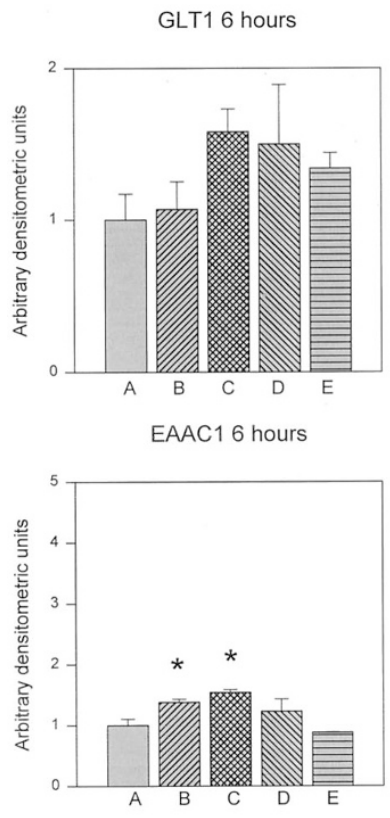

GLAST1 6 hours
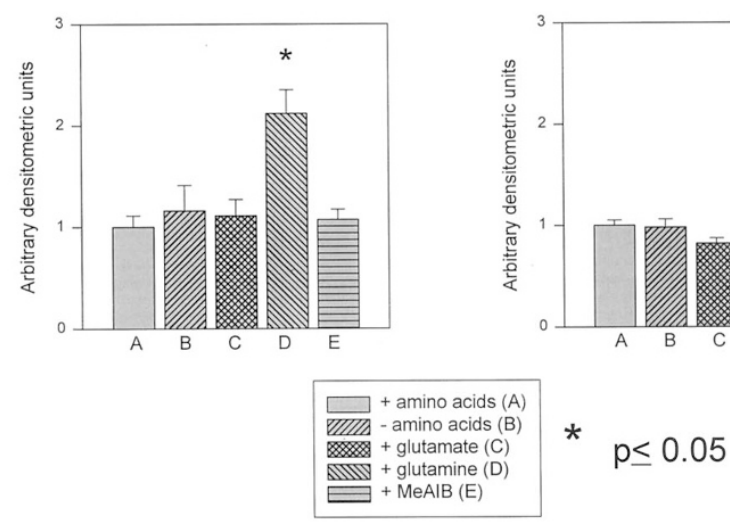

Figure 5. Densitometric analysis of protein expression in Rcho-1 cells. Densitometry was performed as described in "Methods" and normalized within experiments to that in the presence of amino acids. Values depicted are mean \pm SE. Significant differences were determined through the application of two-tailed $t$ test $(* p \leq 0.05)$.

differ. These data suggest that glutamate transfer attributable to GLT1 assumes increasing importance with longer periods of amino acid depletion.

\section{DISCUSSION}

The maternal/fetal "glutamine-glutamate cycle" has been carefully defined in the ovine model (12, 13, 27-29). Maternal glutamine is transferred across the placenta to the fetal circulation, extracted by the fetal liver, and then deaminated for nitrogen utilization and release of glutamate. Glutamate thus derived is then returned to the placenta, where the majority is oxidized to $\mathrm{CO}_{2}$ and $\mathrm{H}_{2} \mathrm{O}$. We previously have demonstrated, through immunohistochemical studies, the presence of three proteins known to mediate $\mathrm{Na}^{+}$-dependent, D-aspartateinhibitable anionic amino acid transport [GLAST1 (30), GLT1 (31), EAAC1 (32)], previously defined as System $\mathrm{X}_{\mathrm{AG}}{ }^{-}$, in rat placenta (17). We have subsequently documented the presence of these proteins in a cell line derived from rat trophoblast

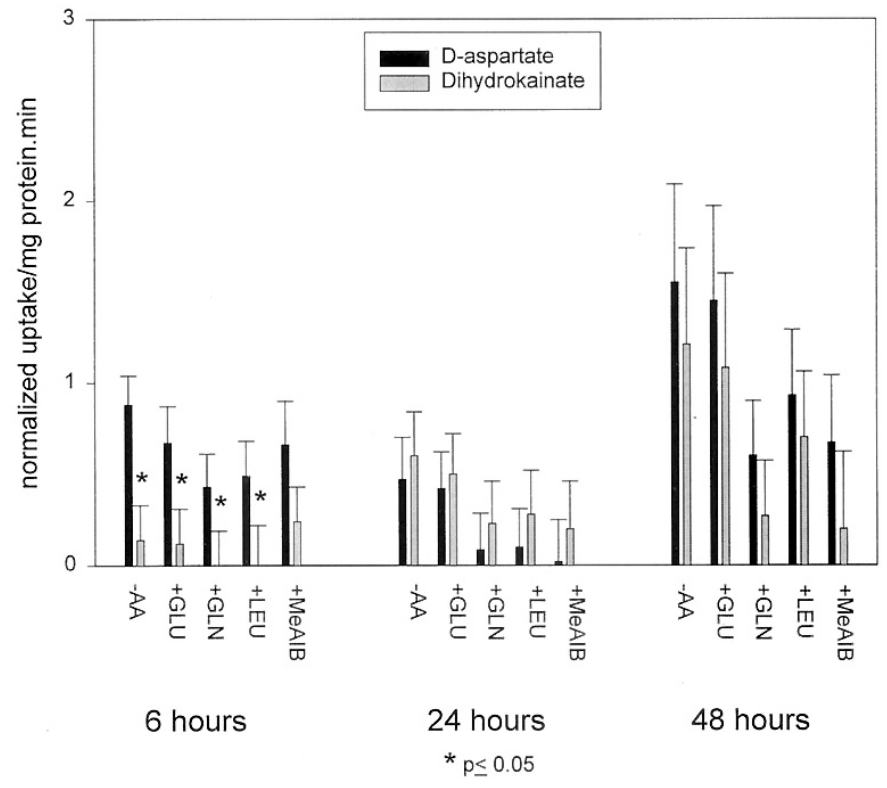

Figure 6. Inhibition of amino acid depletion-induced glutamate uptake by DHK and D-aspartate. All uptakes (1 min) were performed with $1 \mu \mathrm{M}$ $\left[{ }^{3} \mathrm{H}\right]$ glutamate in the presence of a $100-\mathrm{mM}$ inwardly directed $\mathrm{Na}^{+}$gradient with and without $1 \mathrm{mM}$ DHK or $500 \mu \mathrm{M}$ D-aspartate. Shown for each depicted medium is the difference between uptake in the presence or absence of inhibitor (either D-aspartate or DHK), minus the same value obtained in amino acid-replete media. Each point represents the mean $\pm \mathrm{SE}$ of six individual observations normalized (to compensate for interexperiment variability) to total uptake of $1 \mu \mathrm{M}\left[{ }^{3} \mathrm{H}\right]$ glutamate in the presence of amino acids from three temporally separate experiments. Potential differences were determined through use of the test of means of differences (induced uptake; ${ }^{*} p \leq 0.05$ ).

(HRP.1 cells) and delineated their regulation by amino acid availability (24). The current studies examine anionic amino acid uptake and its regulation in a cell line that models placental marginal giant cells.

The findings of this study contrast with those referred to above in HRP.1 cells. Whereas System $\mathrm{X}_{\mathrm{AG}}{ }^{-}$-mediated glutamate uptake is present in both cell lines, that in Rcho-1 cells is approximately 1 order of magnitude lower than that in HRP.1 cells at comparable time points (24). Although data obtained from the in vitro study of cell lines must always be compared with caution to that present in vivo, these data suggest differing capacities for substrate passage into these cell types. In contrast to HRP.1 cells, uptake of glutamate into Rcho-1 cells does not seem to be regulated by glutamate sufficiency. This suggests the need for a constant supply of this amino acid, regardless of extracellular concentrations. Conflicting data exist regarding variations in maternal serum glutamate levels in pregnancies complicated by intrauterine growth retardation, having been reported both as diminished or unchanged $(33,34)$. Fetal serum levels seem unchanged in both groups. We have reported similar findings in animals fed a protein-restricted diet (35). Limited available evidence suggests that placental tissue concentrations rise in pregnancies complicated by growth retardation (36). Even in the normal situation, however, in vivo placental tissue glutamate concentrations are among the highest of any of the amino acids (37). In vitro, however, intracellular glutamate metabolism may be sufficiently rapid to prevent the rise of intracellular concentra- 
tions, with subsequent down-regulation of transfer. Alternatively, transfer may be regulated by an amino acid not tested in this study.

We have demonstrated the presence of three anionic amino acid transfer proteins, GLAST1, GLT1, and EAAC1, in Rcho-1 cells. This observation correlates with that previously made in marginal giant cells in situ (17). As in HRP.1 cells, GLT1-mediated glutamate uptake assumes increased importance under conditions of amino acid depletion, despite the overall decrement in cellular GLT1 content. We hypothesize that this discrepancy may be explained by an increase in the surface expression of this transport protein, as we have shown in HRP. 1 cells (24).

In a seeming paradox, EAAC1 content increased with amino acid deprivation at $48 \mathrm{~h}$, whereas DHK-insensitive System $\mathrm{X}_{\mathrm{AG}}{ }^{-}$-mediated glutamate uptake did not. Possible explanations for this phenomenon include a concurrent decrease in glutamate transfer mediated by GLAST1 or the possibility that whole-cell EAAC1 content does not correlate directly with EAAC1-mediated glutamate transfer. This possibility is consistent with the recent identification of a distinct protein (GTRAP3-18) involved in the regulation of EAAC1 (38). Other potential regulators of the anionic amino acid transfer proteins include the insulin-like growth factors, epidermal growth factor, fibroblast growth factor, protein kinase $\mathrm{C}$, and phosphatidyl inositol 3 kinase (39-41).

\section{CONCLUSION}

In summary, System $\mathrm{X}_{\mathrm{AG}}{ }^{-}$-mediated glutamate uptake and transport proteins associated with that activity are present in Rcho-1 cells derived from rat placenta. Uptake is stimulated by amino acid deprivation but is not suppressed by glutamate sufficiency. These data, when considered in the context of that obtained both in situ and in a cell line derived from an anatomically and functionally distinct placental cell type, confirm that glutamate transfer within the placenta is heterogenous, in both its magnitude and its regulation.

\section{REFERENCES}

1. Davies J, Glasser SR 1968 Histological and fine structural observations on the placenta of the rat. Acta Anat (Basel) 69:542-608

2. Soares MJ, Chapman BM, Rasmussen CA, Dai G, Kamei T, Orwig KE 1996 Differentiation of trophoblast endocrine cells. Placenta 17:277-289

3. Lee S, Talamantes F, Wilder e, Linzer D, Nathans D 1988 Trophoblastic giant cells of the mouse placenta as the site of proliferin synthesis. Endocrinology 122:17611768

4. Faria TN, Ogren L, Talamantes F, Linzer D, Soares MJ 1991 Localization of placental lactogen-I in trophoblast giant cells of the mouse placenta. Biol Reprod 44:327-331

5. Yamaguchi M, Ogren L, Endo H, Soares MJ, Talamantes F 1994 Co-localization of placental lactogen-I, placental lactogen-II, and proliferin in the mouse placenta at midpregnancy. Biol Reprod 51:1188-1192

6. Johnson DC 1992 P45017 alpha (CYP17): 17 alpha-hydroxylase/C17, 20-lyase activity. Biol Reprod 46:30-38

7. Yamamoto T, Chapman BM, Johnson DC, Givens CR, Mellon SH, Soares MJ 1996 Cytochrome F450-17 alpha-hydroxylase gene expression in differentiating rat trophoblast cells. J Endocrinol 150:161-168

8. Gibori G, Khan I, Warshaw ML, McLean MP, Puryear TK, Nelson S, Durkee TJ, Azhar S, Steinschneider A, Rao MC 1988 Placental-derived regulators and the complex control of luteal cell function. Recent Prog Horm Res 44:377-397

9. Broeder JA, Smith CH, Moe AJ 1994 Glutamate oxidation by trophoblasts in vitro. Am J Physiol 267:C189-C194

10. Moe AJ, Farmer DR, Nelson D, Smith CH 1991 Pentose phosphate pathway in cellular trophoblasts from full-term human placentas. Am J Physiol 261:C1042C1047
11. Shafrir E, Diamant YZ 1978 Regulation of placental enzymes of the carbohydrate and lipid metabolic pathways. Ciba Found Symp 1:161-179

12. Barbera A, Wilkening RB, Teng C, Battaglia FC, Meschia G 1997 Metabolic alterations in the fetal hepatic and umbilical circulations during glucocorticoidinduced parturition in sheep. Pediatr Res 41:242-248

13. Vaughn PR, Lobo C, Battaglia FC, Fennessey PV, Wilkening RB, Meschia G 1995 Glutamine-glutamate exchange between placenta and fetal liver. Am J Physiol 268:705-711

14. Klimek J, Swierczynski W, Bossy-Bukato G, Zelewski L 1993 Mitochondrial glutamine and glutamate metabolism in human placenta and its possible link with progesterone biosynthesis. Trophoblast Res 7:77-86

15. Faria TN, Soares MJ 1991 Trophoblast cell differentiation: establishment, characterization, and modulation of a rat trophoblast cell line expressing members of the placental prolactin family. Endocrinology 129:2895-2906

16. Dai G, Imagawa W, Liu B, Szpirer C, Levan G, Kwok SCM, Soares MJ 1996 Rcho-1 trophoblast cell placental lactogens: complementary deoxyribonucleic acids, heterologous expression, and biological activities. Endocrinology 137:5020-5027

17. Matthews JC, Beveridge MJ, Malandro MS, Rothstein JD, Campbell-Thompson M, Verlander J, Kilberg MS, Novak DA 1998 Activity and protein localization of multiple glutamate transporters in gestation-days-14 vs. -20 rat placenta. Am J Physiol 274:C603-C614

18. Hunt JS, Soares MJ 1988 Expression of histocompatibility antigens, transferrin receptors, intermediate filaments, and alkaline phosphatase by in vitro cultured rat placental cells and rat placental cells in situ. Placenta 9:159-171

19. Hunt JS, Deb S, Faria TN, Wheaton D, Soares MJ 1989 Isolation of phenotypically distinct trophoblast cell lines for normal rat chorioallantoic placentas. Placenta 10:161-177

20. Kilberg MS 1989 Measurement of amino acid transport by hepatocytes in suspension or monolayer culture. Methods Enzymol 173:564-575

21. Laemmli UK 1970 Cleavage of structural proteins during the assembly of the head of bacteriophage T4. Nature 227:680-685

22. Rothstein JD, Martin L, Levey AI, Dykes-Hoberg M, Jin L, Wu D, Nash N, Kuncl RW 1994 Localization of neuronal and glial glutamate transporters. Neuron 13:713725

23. Haugeto O, Ullensvang K, Levy LM, Chaudhry FA, Honore T, Nielsen M, Lehre KP, Danbolt NC 1996 Brain glutamate transporter proteins form homomultimers. J Biol Chem 271:27715-27722

24. Novak D, Quiggle F, Artime C, Beveridge M 2001 Regulation of glutamate transport and transport proteins in a placental cell line. Am J Physiol 281:C1014-C1022

25. Plakidou-Dymock S, McGivan JD 1993 Regulation of the glutamate transporter by amino acid deprivation and associated effects on the level of EAAC1 mRNA in the renal epithelial cell line NBL-I. Biochem J 295:749-755

26. Bridges RJ, Kavanaugh MP, Chamberlin AR 1999 A pharmacological review of competitive inhibitors and substrates of high-affinity, sodium-dependent glutamate transport in the central nervous system. Curr Pharm Des 5:363-379

27. Marconi AM, Battaglia FC, Meschia G, Sparks JW 1989 A comparison of amino acid arteriovenous differences across the liver and placenta of the fetal lamb. Am J Physiol 257:E909-E915

28. Liechty EA, Kelley J, Lemons JA 1991 Effect of fasting on uteroplacental amino acid metabolism in the pregnant sheep. Biol Neonate 60:207-214

29. Moores RR, Vaughn PR, Battaglia FC, Fennessey PV, Wilkening RB, Meschia G 1994 Glutamate metabolism in fetus and placenta of late-gestation sheep. Am J Physiol 267:R89-R96

30. Storck T, Schulte S, Hofmann K, Stoffel W 1992 Structure, expression, and functional analysis of a $\mathrm{Na}^{+}$-dependent glutamate/aspartate transporter from rat brain. Proc Natl Acad Sci U S A 89:10955-10959

31. Pines G, Danbolt NC, Bjoras M, Zhang Y, Bendahan A, Eide L, Koepsell H, Storm-Mathisen J, Seeberg E, Kanner BI 1992 Cloning and expression of a rat brain L-glutamate transporter. Nature 360:464-467

32. Kanai Y, Hediger MA 1992 Primary structure and functional characterization of a high-affinity glutamate transporter. Nature 360:467-471

33. Cetin I, Marconi AM, Bozzetti P, Sereni LP, Corbetta C, Pardi G, Battaglia FC 1988 Umbilical amino acid concentrations in appropriate and small-for-gestational-age infants: a biochemical difference present in utero. Am J Obstet Gynecol 158:120-126

34. Economides DL, Nicolaides KH, Gahl WA, Bernadini I, Evans MI 1989 Plasma amino acids in appropriate- and small-for-gestational age fetuses. Am J Obstet Gynecol 161:1219-1227

35. Malandro MS, Beveridge MJ, Kilberg MS, Novak DA 1996 Effect of a low-protein diet induced intrauterine growth retardation on rat placental amino acid transport. Am J Physiol 271:C295-C303

36. Morris NH, Burston D, Ramsay B, Sooranna SR 1995 Free amino acid concentrations in normal and abnormal third trimester placental villi. Eur J Clin Invest 25:796-798

37. Yudilevich DL, Sweiry JH 1985 Transport of amino acids in the placenta. Biochim Biophys Acta 822:169-201

38. Lin CI, Orlov I, Ruggiero AM, Dykes-Hoberg M, Lee A, Jackson M, Rothstein JD 2001 Modulation of the neuronal glutamate transporter EAAC1 by the interacting protein GTRAP3-18. Nature 410:84-88

39. Suzuki K, Ikegaya Y, Matsuura S, Kanai Y, Endou H, Matsuki N 2001 Transient upregulation of the glial glutamate transporter GLAST in response to fibroblast growth factor, insulin-like growth factor and epidermal growth factor in cultured astrocytes. J Cell Sci 114:3717-3725

40. Gamboa C, Ortega A 2002 Insulin-like growth factor-1 increases activity and surface levels of the GLAST subtype of glutamate transporter. Neurochem Int 40:397-403

41. Trotti D, Peng JB, Dunlop J, Hediger MA 2001 Inhibition of the glutamate transporter EAAC1 expressed in Xenopus oocytes by phorbol esters. Brain Res 914:196-203 